\title{
ANALISIS FAKTOR RISIKO TUBERKULOSIS PARU DI WILAYAH KERJA PUSKESMAS KALIGONDANG KABUPATEN PURBALINGGA TAHUN 2017
}

\author{
May Fadilla*), Budi Utomo*) \\ Jurusan Kesehatan Lingkungan, Politeknik Kesehatan Kemenkes Semarang, \\ Jl.Raya Baturaden KM 12 Purwokerto, Indonesia
}

\begin{abstract}
Abstrak
Penyakit TBC di Indonesia merupakan penyebab kematian terbesar ketiga dan penyebab kematian terbesardalam kelompokpenyakit infeksi.Setiap tahunnya terjadi 583.000 penderita baru dan kematian karena TBC sekitar 140.000 dan setiap 100.000 penduduk Indonesia terdapat 130 penderita TBC denganBTA. Tujuan penelitian ini menganalisis hubungan antara riwayat kontak, kelembaban, pencahayaan dan kepadatan hunian dengan penyakit Tuberkulosis paru di wilayah kerja Puskesmas Kaligondang.Jenis penelitian yang digunakan dalam penelitian ini adalah penelitian observasional dengan menggunakan case control study (penelitian kasus pembanding). Metode analisis yang digunakan adalah analisis univariat dan biariat dengan uji chi-square.Hasil penelitian menunjukkan bahwa variabel yang berpengaruh terhadap kejadian TB Paru adalah riwayat kontak $(p-0,002)$ pencahayaan kamar tidur ( $p-$ $0,000)$, dan jenis lantai $(p-0,022)$ sedangkan pencahayaan ruang keluarga $(p-0,240)$ kelembaban $(p-0,215)$ dan kepadatan kepadatan hunian (p-0,132).Peneliti menyimpulkan bahwa variabel yang berhubungan dengan kejadian TB paru adalah riwayat kontak, pencahayaan kamar tidur dan jenis lantai. Peneliti menyarankan kepada warga agar meningkatkan Pola Hidup Bersih dan Sehat (PHBS) dan meminimalisir kontak dengan penderita TB Paru, bagi tenaga kesehatan diharapkan memberikan penyuluhan tentang tanda dan gejala, cara penularan dan cara pencegahan tuberkulosis paru.
\end{abstract}

Kata kunci:kesehatan lingkungan;TB paru; kondisi fisik rumah

\begin{abstract}
In Indonesia Tuberculosis is the third leading cause of death after cardiovascular disease which considered as deadliest main cause among infectious disease group. Female mortality caused by tuberculosis in women werehigher than mortality due to pregnancy, delivery, and post partum. Every year there were 583,000 incidents and 140,000 were caused fatality. In addition, every 100,000 Indonesians there are 130 TB patients with Acid-resistant bacilli. The research objective was investigating the correlation between contact history, humidity, lighting and occupancy density with pulmonary tuberculosis in Kaligondang Public Health Center.The research method used was observational research with case control study (comparative case study) design. The data analysis method used was univariate and bivariate analysis with chi-square test.The analysis results showed that variables affecting pulmonary TB incidence were contact history ( $p$-value 0.002) bedroom illumination (p-value 0,000), and floor type ( $p$-value 0.022) while living room illumination ( $p-0.240)$ humidity ( $p-0.215$ ) And occupancy density ( $p-0.132)$ had no significant correlation with pulmonary TB incidence.The conclution drawn was; variables that had significant correlation with pulmonary $T B$ incidence were contact history, bedroom illumination and floor type. The researcher suggested to the community to improve Clean and Healthy Lifestyle (PHBS) and minimize the contact with Pulmonary TB patient, for health worker is suggested giving counseling about the signs and symptoms, the transmission mode, and pulmonary tuberculosis prevention.
\end{abstract}

Keywords:environmental health; Pulmonary TB, Housing Physical Condition 


\section{Pendahuluan}

Tuberkulosis (TB) adalah suatu infeksi yang disebabkan oleh kuman TB (Mycobacterium tuberculosis). Infeksi ini paling sering mengenai paru, tetapi dapat juga mengenai organ tubuh lainnya (Pedoman Nasional Penanggulangan TB, 2008). Penularan penyakit ini melalui perantaraan ludah atau dahak penderita yang mengandung basil tuberkulosis paru. Pada waktu penderita batuk, butir-butir air ludah beterbangan di udara dan terhisap oleh orang yang sehat dan masuk ke dalam paru-parunya yang kemudian menyebabkan penyakit tuberkulosis paru (Aditama, 1994).

Tuberkulosis paru (TB paru) merupakan masalah utama bidang kesehatan di seluruh dunia. Sampai tahun 2011 tercatat 9 juta kasus baru TB, dan lebih dari 2 juta orang meninggal akibat TB. Semua negara di dunia menyumbang kasus TB,namun persentase terbanyak terjadi di Afrika (30\%) dan Asia (55\%) dengan China dan India tercatat menyumbang $35 \%$ dari total kasus di Asia (WHO, 2011). TB paru memberikan morbiditas dan mortalitas yang tinggi. Mortalitas dan morbiditas meningkat sesuai dengan umur, pada orang dewasa lebih tinggi pada laki-laki. Morbiditas TB lebih tinggi diantara penduduk miskin dan daerahperkotaan jika dibandingkan dengan pedesaan (Chin, 2000). Sejak tahun 1995program pemberantasan TB paru dilaksanakan secara koordinasi dalam suatuprogram yang disebut strategi Directly Observed Treatment Shortcourse (DOTS)sesuai rekomendasi World Health Organization (WHO) (Kemenkes, 2011).Prevalensi tuberkulosis per 100.000 penduduk Provinsi Jawa Tengahtahun 2012 sebesar 106,42. Prevalensi tuberkulosis tertinggi berada di Kota Tegal(358,91 per 100.000 penduduk), dan terendah di Kabupaten Magelang (44,04 per 100.000 penduduk) (Dinkes Jateng, 2013).

Sebagai bagian dari persyaratan kesehatan lingkungan di rumah sakit menurut Kepmenkes RI No. 1204/MENKES/SK/X/2004 dalam lingkup persyaratan lingkungan bangunan rumah sakit, salah satu persyaratan yang diatur didalamnya adalah tentang persyaratan kualitas udara ruangan di rumah sakit. Kualitas udara di rumah sangat dipengaruhi oleh berbagai kegiatan dan kondisi sanitasi udara dalam ruangan yang dapat menyebabkan peningkatan jumlah angka kuman di udara.

Di Indonesia pada tahun 2013 ditemukan jumlah kasus baru BTA (+) sebanyak 196.310 kasus, menurun bila dibandingkan kasus baru BTA (+) yang ditemukan tahun 2012 yang sebesar 202.301 kasus. Jumlah 3 kasus tertinggi yang dilaporkan terdapat di provinsi dengan

${ }^{*}$ E-mail: fadilla.may10@yahoo.co.id

${ }^{* *)}$ E-mail: budut17@yahoo.com jumlah penduduk yang besar yaitu Jawa barat, Jawa Timur, dan Jawa Tengah. Kasus BTA (+) di tiga provinsi tersebut hampir sebesar $40 \%$ dari jumlah seluruh kasus baru di Indonesia. Menurut jenis kelamin, kasus BTA (+) pada laki-laki lebih tinggi daripada perempuan yaitu hampir 1,5 kali dibandingkan kasus BTA (+) pada perempuan. Sedangkan menurut kelompok umur, kasus baru yang ditemukan paling banyak pada kelompok umur 25-34 tahun yaitu sebesar 21,40\%, diikuti kelompok umur 35-44 tahun sebesar 19,41\% dan pada kelompok umur 45-54 tahun sebesar 19,39\%. (Profil Kesehatan Indonesia,2013)

World Health Organization (WHO) merekomendasikan strategi Directly Observed Treatment Short-Cours) (DOTS) sebagai upaya pendekatan kesahatan yang paling tepat saat ini untuk menanggulangi masalah TBC di Indonesia khususnya keberhasilan dalam penemuan kasus TBC yang diharapkan dapat mencapai target. Beberapa fokus utama dalam pencapain target yaitu pengawasan minum obat, memperkuat mobilisasi, dan advokasi serta memperkuat kemitraan dan kolaborasi dengan berbagai tingkat. (Anonim,2008)

Kondisi rumah dan lingkungan yang tidak memenuhi syarat kesehatan merupakan faktor risiko sumber penularan penyakit TB Paru. Sumber penularan penyakit ini erat kaitannya dengan kondisi sanitasi rumah, faktor risiko dan lingkungan pada bangunan rumah yang dapat mempengaruhi kejadian penyakit maupun kecelakaan antara lain: ventilasi, pencahayaan, kepadatan hunian, kelembaban ruangan, binatang penular penyakit, penyediaan air bersih, limbah rumah tangga, hingga penghuni dalam rumah. (Direktorat Jendral PPM \& PL,2002,Hal 2).

Faktor penyebab TB Paru, menurut Tambayong (2000) faktor penyebab TB Paru ini meliputi, Adapun faktor yang memengaruhi kejadian tuberkulosis diantaranya, a. Faktor intrinsik: 1) Umur, beberapa faktor resiko penularan penyakit tuberkulosis di Amerika yaitu umur, jenis kelamin. Dari hasil penelitian yang dilaksanakan di New York pada Panti penampungan orang-orang gelandangan menunjukkan bahwa kemungkinan mendapat infeksi tuberkulosis aktif meningkat secara bermakna sesuai dengan umur (Elizabet,2009). 2) Jenis Kelamin, TB paru Iebih banyak terjadi pada laki-laki dibandingkan dengan wanita karena laki-laki sebagian besar mempunyai kebiasaan merokok sehingga memudahkan terjangkitnya TB paru. (Corwin, 2009). 3) Pendidikan, tingkat pendidikan seseorang akan mempengaruhi terhadap pengetahuan seseorang diantaranya mengenai rumah yang memenuhi syarat kesehatan dan pengetahuan penyakit TB Paru. 4) Pekerjaan, jenis pekerjaan menentukan faktor risiko apa yang harus dihadapi setiap individu (Corwin,2009).5) Status Gizi, Kekurangan gizi pada seseorang akan berpengaruh terhadap kekuatan daya tahan tubuh dan 
respon immunologik terhadap penyakit, ( Isselbacher,2009). 6) Pengetahuan, pengetahuan adalah merupakan hasil tahu dan ini terjadi setelah orang melakukan penginderaan terhadap suatu objek tertentu (Notoatmodjo, 2002).

Faktor Extrinsik: 1) Ventilasi, adalah untuk menjaga agar aliran udara didalam rumah tersebut tetap segar. Hal ini berarti keseimbangan oksigen yang diperlukan oleh penghuni rumah tersebut tetap terjaga (Somantri, 2007). 2) Pencahayaan, untuk memperoleh cahaya cukup pada siang hari, diperlukan luas jendela kaca minimum 20\% luas lantai. Cahaya ini sangat penting karena dapat membunuh bakteri-bakteri patogen di dalam rumah, misalnya basil TB, karena itu rumah yang sehat harus mempunyai jalan masuk cahaya yang cukup.(Somantri, 2007). 3) Keadaan Sosial Ekonomi, keadaan sosial ekonomi berkaitan erat dengan pendidikan, keadaan sanitasi lingkungan, gizi dan akses terhadap pelayanan kesehatan, (Darmanto, 2007). 4) Kondisi rumah, kondisi rumah dapat menjadi salah satu faktor resiko penularan penyakit TB Paru. Atap, dinding dan lantai dapat menjadi tempat perkembang biakan kuman (Tambayong, 2000). 5) Kelembaban udara, kelembaban udara dalam ruangan untuk memperoleh kenyamanan, dimana kelembaban yang optimum berkisar $60 \%$ dengan temperatur kamar $22^{\circ}-30^{\circ} \mathrm{C}$. Kuman TB Paru akan cepat mati bila terkena sinar matahari langsung, tetapi dapat bertahan hidup selama beberapa jam di tempat yang gelap dan lembab (Tambayong, 2000). 6) Kepadatan hunian, luas lantai bangunan rumah sehat harus cukup untuk penghuni di dalamnya. Luas minimum per orang sangat relatif tergantung dari kualitas bangunan dan fasilitas yang tersedia. Untuk rumah sederhana luasnya minimum 10 m2/orang (Corwin, 2009).

Hasil penelitian Ning Budiarti (2009) menunjukan hubungan yang bermakna antara kondisi fisiologis rumah dengan kejadian tuberkulosis yaitu kepadatan penghuni ( $\mathrm{p}=0,031$ dan OR 2,368), ventilasi rumah ( $\mathrm{p}=0,031$ dan OR 2,368), pencahayaan alami ( $\mathrm{p}-$ 0,001 dan OR 3,908). Adapun hasil penelitian Suprijono (2005) menyatakan bahwa umur penderita TB paru yang gagal konversi di kabupaten Purworejo dan sekitarnya terbanyak 31-45 tahun (41,2\%), tingkat pendidikan terbanyak SD (53\%), status pekerjaan tidak mempunyai penghasilan tetap (94\%), dan faktor risiko yang mempengaruhi konversi dahak adalah : ketidak teraturan minum obat dan gejala efek samping obat. Fahrudda (2001) mendapatkan hasil bahwa tingkat pengetahuan penderita yang dikategorikan rendah akan berisiko lebih dari 2 kali untuk terjadi kegagalan pengobatan dibandingkan dengan penderita dengan tingkat pengetahuan tinggi.

Berdasarkan latar belakang tersebut maka rumusan masalah dalam penelitian ini adalah “Apakah ada Hubungan Riwayat Kontak, Kelembaban,
Pencahayaan dan Kepadatan Hunian dengan Kejadian Tuberkulosis Paru di Wilayah Kerja Puskesmas Kaligondang ? “

Tujuan penelitian ini untuk mengetahui Hubungan Riwayat Kontak, Kelembaban, Pencahayaan dan Kepadatan Hunian dengan Kejadian Tuberkulosis Paru di Wilayah Kerja Puskesmas Kaligondang Kabupaten Purbalingga.

\section{Bahan dan Metode}

Penelitian ini bersifat deskriptif observasional dengan metode pendekatan case control studyyaitu melakukan penelitian dengan kasus pembandingMetode analisis yang digunakan adalah analisis univariat dan bivariat dengan uji chi-square. Pengumpulan data dilakukan dengan observasi dan wawancara mengenai kepadatan hunian rumah penderita TB paru dan bukan penderita TB paru.

\section{Hasil dan Pembahasan}

Berdasarkan hasil penelitianAnalisis Faktor Risiko Tuberkolosis di Wilayah Kerja Puskesmas Kaligondang Kabupaten Purbalingga Tahun 2017, dapat dilihat pada hasil dan pembahasansebagai berikut :

\section{a. Gambaran Umum Puskesmas Kaligondang}

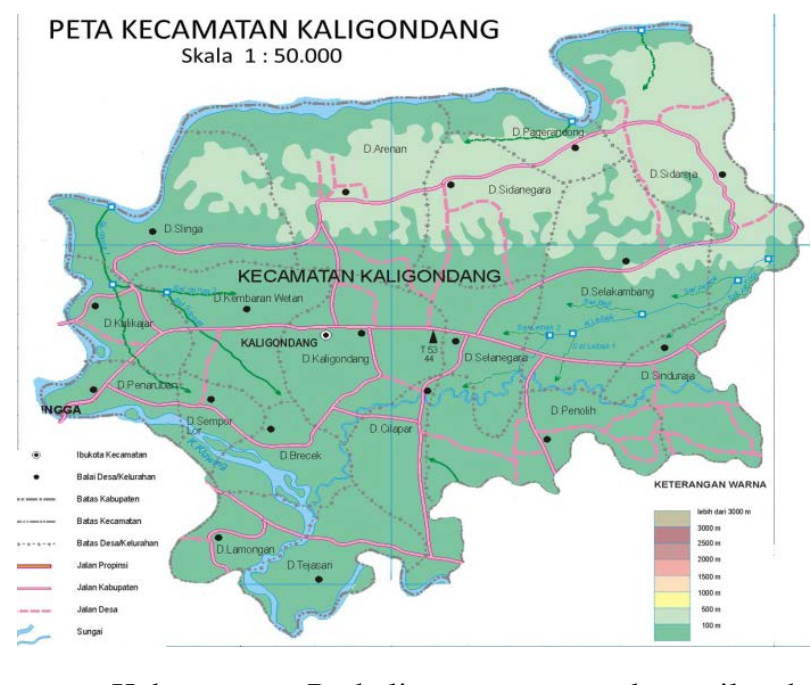

Kabupaten Purbalingga termasuk wilayah Propinsi Jawa Tengah bagian barat daya, tepatnya pada posisi : 109011 - 1090351 Bujur Timur, dan 7010170291 Lintang Selatan. Salah satu kecamatan di kabupaten Purbalingga adalah Kecamatan Kaligondang. Di Kecamatan Kaligondang sendiri terdapat 2 (dua) sarana kesehatan yang bernaung dibawah Pemerintah Kabupaten Purbalingga yaitu UPTD Puskesmas Kaligondang dan UPTD Puskesmas Kalikajar. Selain dua sarana kesehatan tersebut terdapat satu Rumah Sakit Ibu dan Anak yang terletak di desa kalikajar.

Puskesmas Kaligondang memiliki tiga Puskesmas Pembantu dalam meningkatkan kualitas dan 
kuantitas pelayanan yaitu Puskesmas Pembantu Sidanegara, Puskesmas Pembantu Sidareja, Puskesmas Pembantu Selakambang.Disamping itu ada juga pelayanan kesehatan yang terletak di tiap desa, yaitu Poliklinik Kesehatan Desa (PKD) yang terletak hampir tiap desa.Desa yang sudah didirikan PKD yaitu Selanegara, Cilapar, Penolih, Selakambang, Sidareja, Pagerandong, Arenan, Sinduraja.Batas-batas administratif Puskesmas Kaligondang adalah sebelah utara berbatasan dengan kecamatan karanganyar, sebelah timur berbatasan dengan kecamatan pengadegan, sebelah selatan berbatasan dengan kecamatan bukateja dan sebelah barat berbatasan dengan kecamatan purbalingga. Wilayah kerja yang dimiliki UPTD Puskesmas Kaligondang terdiri atas 10 desa yaitu Desa Kaligondang, Selanegara, Cilapar, Penolih, Sinduraja, Selakambang, Sidareja, Pgerandong, Sidanegara dan Arenan.Luas wilayah kerja Puskesmas Kaligondang adalah $3.504,30 \mathrm{~km}^{2}$, desa yang terluas adalah desa Selakambang dengan luas wilayah adalah $609,64 \mathrm{~km}^{2}$, sedangkan desa yang terkecil adalah desa Pagerandong yaitu 223,37 $\mathrm{km}^{2}$.

\section{1)Kondisi Demografi}

Jumlah penduduk di wilayah Puskesmas Kaligondang pada tahun 2016 adalah 55.273 jiwa dengan jumlah penduduk laki-laki sebanyak 28.301 jiwa dan penduduk perempuan sebanyak 26.972 jiwa. Wilayah kerja Puskesmas Kaligondang yang mempunyai kepadatan penduduk tinggi yaitu Desa Sinduraja dengan jumlah penduduk 4.875 jiwa dan luas wilayah $269 \mathrm{~km}^{2}$ sehingga diperoleh angka kepadatan penduduk 1812,3 jiwa $/ \mathrm{km}^{2}$. Sedangkan wilayah Puskesmas Kaligondang dengan jumlah penduduk terbanyak adalah Desa Selakambang yaitu 7.782 jiwa, akan tetapi Desa Selakambang mempunyai luas wilayah yang sangat luas sehingga tidak terjadi kepadatan penduduk yang tinggi. Desa yang mempunyai jumlah penduduk paling sedikit yaitu Desa Cilapar dengan jumlah penduduk 2.106 jiwa.Tingkat pendidikan pada tahun 2016, sebagian besar penduduk wilayah kerja Puskesmas Kaligondang tamat Sekolah Dasar dan Sekolah Lanjutan Tingkat Pertama (SLTP) yaitu $17.740(60,40 \%)$ dan ini merupakan jumlah terbanyak dari jumlah yang mengenyam pendidikan, sedangkan jumlah tingkat pendidikan terkecil adalah lulusan universitas yaitu 235 (0,80\%).

2) Keadaan Lingkungan

a) Rumah Sehat

Rumah sehat adalah bangunan yang memenuhi syarat kesehatan, yaitu bangunan yang memiliki jamban yang sehat, sarana air bersih, tempat pembuangan sampah, sarana pembuangan air limbah, ventilasi rumah, rumah hunian yang sesuai dan lantai rumah tidak terbuat dari tanah. Jumlah rumah yang ada di wilayah kerja Puskesmas Kaligondang tahun 2016 sebanyak 10.222 buah. Sedangkan jumlah yang memenuhi syarat kesehatan sebanyak 7.483 (83,06\%).

b)Tempat Umum dan Pengolahan Makanan

Tempat-tempat Umum dan Pengolahan Makanan (TUPM) merupakan suatu sarana yang berpotensi menjadi tempat persebaran penyakit Jenis TUPM meliputi : hotel, rumah makan / restoran, pasar, dan lainlain. TUPM yang sehat adalah yang memenuhi syarat kesehatan yaitu memiliki sarana air bersih, tempat pembuangan sampah, sarana pembuangan air limbah (SPAL), ventilasi yang baik, luar lantai/ruangan sesuai dengan banyaknya pengunjung dan memiliki pencahayaan ruangan yang memadai. Data TUPM yang ada di wilayah kerja Puskesmas Kaligondang tahun 2016 hanya terdiri dari 2 pasar.Dari 2 pasar tersebut di periksa dan memenuhi syarat kesehatan semua.

c) Akses Terhadap Air Minum

Sumber air minum keluarga yang digunakan rumah tangga meliputi air kemasan, ledeng, pompa, sumur terlindung, mata air terlindung, air sungai, air hujan, dan lainnya.Berdasarkan hasil pemeriksaan terhadap sumber air minum keluarga sejumlah 8537 buah, yang memenuhi syarat kesehatan / terlindung sejumlah 7836 buah (92\%).

d)Kepemilikan Sarana Sanitasi Dasar

Kepemilikan sarana sanitasi dasar pada setiap keluarga meliputi : jamban, tempat sampah, dan pengolahan air limbah (PAL). Pemeriksaan terhadap kepemilikan sarana sanitasi dasar yang meliputi kepemilikan jamban, tempat sampah dan pengelolaan air limbah. Jamban dan SPAL merupakan sarana vital yang harus dimiliki oleh setiap rumah tangga akan tetapi tidak semua rumah di wilayah kerja Puskesmas Kaligondang memiliki jamban dan SPAL. Jumlah seluruh rumah yang ada di wilayah Puskesmas Kaligondang pada tahun 2016 yaitu 10.222 rumah. Pada tahun 2016 jumlah rumah yang memiliki jamban yaitu 7750 rumah dan dari rumah- rumah tersebut setelah diperiksa yang memiliki jamban sehat sejumlah 7635 (96\%).

\section{b. Mortalitas}

Gambaran perkembangan derajat kesehatan masyarakat dapat dilihat dari kejadian kematian di masyarakat dari waktu ke waktu.Disamping itu kejadian kematian juga dapat digunakan sebagai indikator dalam penilaian keberhasilan pelayanan kesehatan dan program pembangunan kesehatan lainnya.

\section{c. Morbiditas}

Penyakit menular yang disajikan dalam profil kesehatan Puskesmas Kaligondang pada tahun 2016 antara lain adalah penyakit Malaria, TB Paru, HIV/AIDS, dan Infeksi Saluran Pernapasan Akut (ISPA). 
d. Gambaran Karakteristik Responden

1)Karateristik Responden Menurut Umur

Tabel 1. Responden Menurut Umur

\begin{tabular}{|c|c|c|c|c|c|c|}
\hline \multirow{3}{*}{$\begin{array}{c}\text { Umur } \\
\text { (Tahun) }\end{array}$} & \multicolumn{4}{|c|}{ Kelompok } & \multirow{2}{*}{\multicolumn{2}{|c|}{ Total }} \\
\hline & \multicolumn{2}{|c|}{ Kontrol } & \multicolumn{2}{|c|}{ Kasus } & & \\
\hline & $\mathbf{F}$ & $\%$ & $\mathbf{F}$ & $\%$ & $\mathbf{F}$ & $\%$ \\
\hline$<25$ & 1 & 4,5 & 0 & 0,0 & 1 & 2,3 \\
\hline $25-35$ & 7 & 31,8 & 5 & 22,7 & 12 & 27,3 \\
\hline$>35$ & 14 & 63,6 & 17 & 77,3 & 31 & 70,5 \\
\hline Total & 22 & 100 & 22 & 100 & 44 & 100 \\
\hline
\end{tabular}

paling banyak pada kelompok kasus adalah kelompok umur lebih dari 35 tahun sebanyak 17 orang (77,3\%) sedangkan kelompok kontrol paling banyak adalah kelompok umur lebih dari 35 tahun yaitu sebanyak 14 orang $(63,6 \%)$.

2)Karateristik Responden Menurut Jenis Kelamin

Tabel 2. Responden Menurut Umur

\begin{tabular}{ccccccc}
\hline \multirow{2}{*}{$\begin{array}{c}\text { Jenis } \\
\text { Kelamin }\end{array}$} & \multicolumn{4}{c}{ Kelompok } & \multicolumn{2}{c}{ Total } \\
\cline { 2 - 6 } & \multicolumn{2}{c}{ Kontrol } & \multicolumn{2}{c}{ Kasus } & \multicolumn{2}{c}{} \\
\cline { 2 - 6 } & $\mathbf{F}$ & $\mathbf{\%}$ & $\mathbf{F}$ & $\mathbf{\%}$ & $\mathbf{F}$ & $\mathbf{\%}$ \\
\hline $\mathrm{L}$ & 13 & 59,1 & 9 & 40,9 & 22 & 50,0 \\
$\mathrm{P}$ & 9 & 40,9 & 13 & 59,1 & 22 & 50,0 \\
\hline Total & 22 & 100 & 22 & 100 & 44 & 100 \\
\hline \multicolumn{2}{r}{ Karateristik } & responden & menurut & jenis & kelamin
\end{tabular}
dari total responden sebanyak 44 orang terdiri dari perempuan 22 yaitu (50\%) dan Laki-laki 22 yaitu (50\%). Pada kelompok kasus jenis kelamin laki-laki lebih banyak yaitu 13 sebesar $(59,1 \%)$ dibanding perempuan yaitu 9 sebesar (40,9\%). Sedangkan pada kelompok kontrol jenis kelamin perempuan lebih banyak yaitu 13 sebesar (59,1\%) dibanding laki-laki yaitu 9 sebesar (40,9\%).

3)Karateristik Responden Menurut Tingkat Pendidikan Tabel 3. Responden Menurut Tingkat Pendidikan

\begin{tabular}{ccccccc}
\hline \multirow{2}{*}{$\begin{array}{c}\text { Jenis } \\
\text { Kelamin }\end{array}$} & \multicolumn{4}{c}{ Kelompok } & \multicolumn{2}{c}{ Total } \\
\cline { 2 - 6 } & \multicolumn{2}{c}{ Kontrol } & \multicolumn{2}{c}{ Kasus } & \multicolumn{2}{c}{} \\
\cline { 2 - 6 } & $\mathbf{F}$ & $\mathbf{\%}$ & $\mathbf{F}$ & $\mathbf{\%}$ & $\mathbf{F}$ & $\mathbf{\%}$ \\
\hline SD & 13 & 59,1 & 5 & 22,7 & 18 & 40,9 \\
SMP & 6 & 27,3 & 7 & 31,8 & 13 & 29,5 \\
SMA & 3 & 13,6 & 10 & 45,5 & 13 & 29,5 \\
\hline Total & 22 & 100 & 22 & 100 & 44 & 100 \\
\hline \multicolumn{2}{c}{ Karateristik } & \multicolumn{2}{c}{ responden } & menurut & tingkat
\end{tabular}

pendidikan paling banyak adalah tamat SD yaitu 18 sebesar $(40,9 \%)$ dengan rincian pada kelompok kasus yaitu 5 sebesar (22,7\%) dan kelompok kontrol yaitu 13 sebesar $(59,1 \%)$. Sedangkan tingkat pendidikan paling sedikit adalah SMA yaitu 13 sebesar (29,5\%) dengan rincian kelompok kasus yaitu 10 sebesar (45,5\%) sedangkan kelompok kontrol yaitu 3 sebesar (13,6\%).
4) Karateristik Responden Menurut Jenis Pekerjaan

Tabel 4.Responden Menurut Jenis Pekerjaan

\begin{tabular}{ccccccc}
\hline \multirow{2}{*}{$\begin{array}{c}\text { Jenis } \\
\text { Pekerjaan }\end{array}$} & \multicolumn{4}{c}{ Kelompok } & \multicolumn{2}{c}{ Total } \\
\cline { 2 - 6 } & \multicolumn{2}{c}{ Kontrol } & \multicolumn{2}{c}{ Kasus } & & \\
\cline { 2 - 6 } & $\mathbf{F}$ & $\mathbf{\%}$ & $\mathbf{F}$ & $\mathbf{\%}$ & $\mathbf{F}$ & $\mathbf{\%}$ \\
\hline Buruh & 11 & 50,0 & 7 & 31,8 & 18 & 40,9 \\
IRT & 6 & 27,3 & 7 & 31,8 & 13 & 29,5 \\
Menganggur & 2 & 9,1 & 0 & 0,0 & 2 & 4,5 \\
Pdagang & 2 & 9,1 & 7 & 31,8 & 9 & 20,5 \\
Peternak & 1 & 4,5 & 1 & 4,5 & 2 & 4,5 \\
\hline Total & 22 & 100 & 22 & 100 & 44 & 100 \\
\hline Karateristik & & &
\end{tabular}

paling banyak adalah buruh yaitu 18 sebesar (40,9\%).

Dengan rincian kelompok kasus yaitu 7 sebesar (31,8\%).

Sedangkan pada kelompok kontrol yaitu 11 sebesar (50,0\%).

e. Hasil Analisis

Hasil analisis pada penelitian ini merupakan variabel univariat dan variable bivariat, berikut merupakan hasil dan pembahasannya :

1) Riwayat Kontak

Tabel 5.Distribusi Responden Menurut RiwayatKontak

\begin{tabular}{ccc}
\hline Riwayat Kontak & $\begin{array}{c}\text { Frekuensi } \\
\text { (orang) }\end{array}$ & $\begin{array}{c}\text { Persentase } \\
\text { (\%) }\end{array}$ \\
\hline Tidak Ada & 32 & 72,7 \\
Ada & 12 & 27,3 \\
\hline Total & 44 & 100,0 \\
\hline
\end{tabular}

Dari 44 riwayat kontak pada kelompok kasus dan kelompok kontrol terdapat 32 responden (72.7\%) termasuk kategori tidak memenuhi syarat dan 12 responden (27.3\%) termasuk kategori memenuhi syarat.OR $>1$ yang artinya: riwayat kontak merupakan faktor risiko TB paru.

2) Pencahayaan

Tabel 6.Distribusi Responden Menurut Pencahayaan

\begin{tabular}{ccc}
\hline Pencahayaan & $\begin{array}{c}\text { Frekuensi } \\
\text { (orang) }\end{array}$ & $\begin{array}{c}\text { Persentase } \\
\text { (\%) }\end{array}$ \\
\hline TMS & 8 & 18,2 \\
MS & 36 & 81,8 \\
\hline Total & 44 & 100,0 \\
\hline
\end{tabular}

Dari 44 kelompok kasus dan kontrol terdapat pencahayaan ruang keluarga terdapat 8 responden (18.2\%) termasuk kategori tidak memenuhi syarat dan terdapat 36 responden (81.8\%) termasuk kategori memenuhi syarat. OR $<1$ yang artinya: pencahayaan ruang keluarga bukan merupakan faktor risiko TB paru.

) Pencahayaan Kamar Tidur 
Tabel 7.Distribusi Responden Menurut Pencahayaan di Kamar Tidur

\begin{tabular}{ccc}
\hline $\begin{array}{c}\text { Pencahayaan } \\
\text { Kamar Tidur }\end{array}$ & $\begin{array}{c}\text { Frekuensi } \\
\text { (orang) }\end{array}$ & $\begin{array}{c}\text { Persentase } \\
\text { (\%) }\end{array}$ \\
\hline TMS & 20 & 45,5 \\
MS & 24 & 55,5 \\
\hline Total & 44 & 100,0 \\
\hline
\end{tabular}

Dari 44 kelompok kasus dan kontrol terdapat pencahayaan kamar tidur yaitu 20 responden (45.5\%) termasuk kategori tidak memenuhi syarat dan terdapat 24 responden (54.5\%) termasuk kategori memenuhi syarat.OR $>1$ yang artinya: pencahayaan kamar tidur merupakan faktor risiko TB paru.

4) Kelembaban

Tabel 8.Distribusi Responden Menurut Pencahayaan

\begin{tabular}{ccc}
\hline Kelembaban & $\begin{array}{c}\text { Frekuensi } \\
\text { (orang) }\end{array}$ & $\begin{array}{c}\text { Persentase } \\
\text { (\%) }\end{array}$ \\
\hline TMS & 17 & 38,6 \\
MS & 27 & 61,4 \\
\hline Total & 44 & 100,0 \\
\hline Dari 44 kelompok kasus dan kontrol terdapat 17
\end{tabular}

Dari 44 kelompok kasus dan kontrol terdapat 17 responden (38.6\%) termasuk kategori tidak memenuhi syarat dan 27 responden (61.4\%) termasuk kategori memenuhi syarat.OR $<1$ yang artinya: kelembaban bukan merupakan faktor risiko TB paru.

4) Kepadatan Hunian

Tabel 9.Distribusi Responden Menurut Kepadatan Hunian

\begin{tabular}{ccc}
\hline $\begin{array}{c}\text { Kepadatan } \\
\text { Hunian }\end{array}$ & $\begin{array}{c}\text { Frekuensi } \\
\text { (orang) }\end{array}$ & $\begin{array}{c}\text { Persentase } \\
\text { (\%) }\end{array}$ \\
\hline TMS & 9 & 20,5 \\
MS & 35 & 79,5 \\
\hline Total & 44 & 100,0 \\
\hline
\end{tabular}

Dari 44 kelompok kasus dan kontrol terdapat 9 responden $(20.5 \%)$ termasuk kategori tidak memenuhi syarat dan 35 responden (79.5\%) termasuk kategori memenuhi syarat.OR $<1$ yang artinya: kepadatan hunian bukan merupakan faktor risiko TB paru.

5) Kondisi Lantai

Tabel 10.Distribusi Responden Menurut Kondisi Lantai

\begin{tabular}{ccc}
\hline $\begin{array}{c}\text { Kepadatan } \\
\text { Hunian }\end{array}$ & $\begin{array}{c}\text { Frekuensi } \\
\text { (orang) }\end{array}$ & $\begin{array}{c}\text { Persentase } \\
\text { (\%) }\end{array}$ \\
\hline TMS & 30 & 68,2 \\
MS & 14 & 31,8 \\
\hline Total & 44 & 100,0
\end{tabular}

Dari 44 kelompok kasus dan kontrol terdapat 30 responden (68.2\%) termasuk kategori tidak memenuhi syarat dan 14 responden (31.8\%) termasuk kategori memenuhi syarat.OR $>1$ yang artinya: kondisi lantai merupakan faktor risiko TB paru.

\section{Kesimpulan}

a. Ada hubungan antara riwayat kontak dan pencahayaan kamar tidur dengan kejadian TB Paru di wilayah kerja Puskesmas Kaligondang Kecamatan Kaligondang Kabupaten Purbalingga.

b. Ada hubungan yang signifikan antara riwayat kontak dengan kejadian TB Paru.

c. Ada hubungan yang signifikan antara pencahayaan kamar tidur dengan kejadian TB Paru.

Disarankan untuk penanganan faktor-faktor yang mempengaruhi terjadinya TB Paru dapat dilakukan dengan upaya berikut :

a. Perlunya meningkatkan kesadaran akan pentingnya Pola Hidup Bersih dan Sehat (PHBS) untuk mencegah terjadinya tuberkulosis paru yang berkelanjutan.

b. Penderita TB Paru tidak tidur dengan anggota keluarga lain dan untuk rumah penderita TB Paru perlu diadakan pemasangan genting kaca agar pencahayaan alami yaitu sinar matahari dapat masuk kedalam rumah.

c. Bagi masyarakat yang kepadatan hunian sudah memenuhi syarat diusahakan untuk menjaga kebersihan kamar. Sedangkan untuk masyarakat kepadatan penghuni yang tidak memenuhi syarat bisa diupayakan dengan menata ruangan, barang-barang yang ada dikamar tidak terlalu banyak.

\section{Ucapan Terima Kasih}

Peneliti mengucapkan banyak terima kasih kepada pihak Puskesmas Kaligondang Kabupaten Purbalingga serta seluruh pihak yang telah membantu terselesaikannya penelitian ini.

\section{Daftar Pustaka}

Aditama, T, Y 2000, Tuberkulosis Diagnosis, Terapi dan Masalahnya, Lab. Mikrobiologi RSUP Persahabatan Jakarta.

Barmawi, 2004. Tuberkulosis Ancaman Kegawatan Dunia Aspek Imunologi dan terapi. Yogyakarta : UGM

Baskoro Iwan Santoso (2009) Hubungan kondisi fisiologis rumah dengan kejadian TB BTA (+) di Puskesmas Bobotsari Kabupaten Purbalingga tahun 2009, KTI, Purwokerto: Kementrian Kesehatan RI Politeknik Kesehatan Semarang Jurusan Kesehatan Lingkungan Purwokerto

Basri, C. 2007. Implementasi Strategi DOTS dan Tntangan di Indonesia. Jakarta: Depkes RI.

Corwin Elizabeth J. , 2009, Buku Saku Patofisiologis. Penerbit buku kedokteran Jakarta

Darmanto, Djojodibroto, 2007, Respirologi, penerbit buku kedokteran jakarta

Depkes RI. 1999, Kepmenkes RI N0.829/Menkes/SK/VII/1999, Tentang Persyaratan Kesehatan Perumahan. Jakarta: Departemen Kesehatan Republik Indonesia.

Depkes RI. 2002, Pedoman Nasional Penanggulangan Tuberkulosis, Jakarta: Depkes RI. 
Depkes RI. 2002, Pedoman Teknis Penilain Rumah Sehat, Jakarta: Ditejen PPM dan PLP

Isselbacher, Kurt 2009, Harrison: Prinsip-prinsip Ilmu Penyakit Dalam: (Harrison's Principles of Internal Medicine); Volume 1 penerbit buku kedokteran jakarta

John Crofton, 2002, tuberkulosis klinis, Jakarta: Penerbit widya medika

Keputusan Menteri Kesehatan RI. Nomor : 829/Menkes/SK/VII/1999, Persyaratan Kesehatan Rumah Tinggal, Jakarta : Kepmenkes RI.

Ning Budiarti(2009) Hubungan kondisi fisiologis rumah dengan kejadian Tuberkulosis paru BTA (+) Di Puskesmas bobotsari Kabupaten Purbalingga tahun 2009, KTI, Purwokerto: Kemenentrian Kesehatan RI Politeknik Kesehatan Semarang Jurusan Kesehatan Lingkungan Purwokerto.

Notoatmodjo, 2002. Metode Penelitian Kesehatan. Jakarta : PT. Rhineka Cipta

Notoatmodjo. 2003, Ilmu Kesehatan Masyarakat, Prinsip-Prinsip Dasar, Yogyakarta: PT Rineka Cipta.

Puskesmas Kaligondang. 2017, Laporan kasus Kesakitan tuberkulosis paru tahun 2016, Banyumas

Somantri, Irman, 2007. Asuhan Keperawatan pada pasien dengan gangguan pernafasan, Salemba medika

Tambayong, Jan, 2000, Patofiologis Untuk Keperawatan. Penerbit buku Kedokteran Jakarta

Tri Cahyono, 2009. Tata Cara Penulisan Proposal Penelitian dan Karya Tulis Ilmiah, Purwokerto: Poltekkes Kemenkes Semarang JKL

Tri Wahyuni (2015) Hubungan fisik rumah dengan kejadian TB Paru BTA (+) di wilaya kerja Puskesmas II Kembaran Kabupaten Banyumas tahun 2015, KTI, Purwokerto: Kementrian Kesehatan RI Politeknik Kesehatan Semarang Jurusan Kesehatan Lingkungan Purwokerto

Wirawan Dewa Nyoman, dr. MPH, April 1997. Epidemiologi Dasar. Laboratorium Epidemiologi Jurusan Ilmu Kesehatan Masyarakat Fakultas Kedokteran Universitas Udayana. Denpasar. 